\title{
Punjabi Language
}

National Cancer Institute

\section{Source}

National Cancer Institute. Punjabi Language. NCI Thesaurus. Code C154075.

An Indo-Aryan language spoken by the Punjabi people of northwest India and eastern

Pakistan. 